
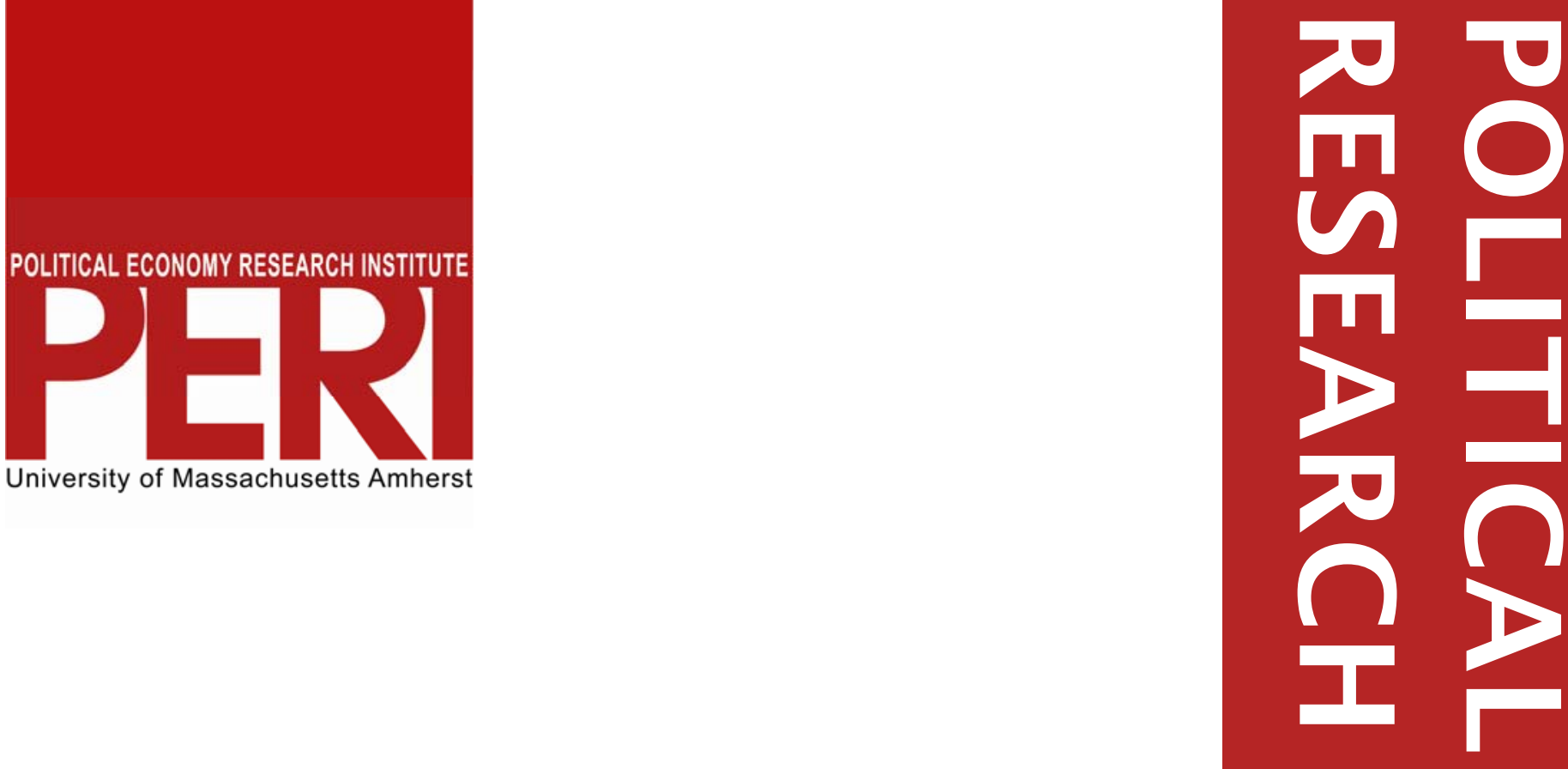

Is There a Case for Formal Inflation Targeting in Sub-Saharan Africa?

James Heintz \& Léonce Ndikumana

March 2010

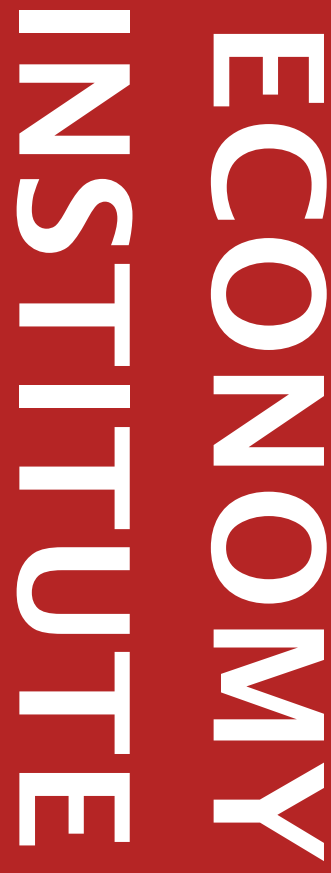

Gordon Hall

418 North Pleasant Street

Amherst, MA 01002

Phone: 413.545 .6355

Fax: 413.577 .0261

peri@econs.umass.edu

www.umass.edu/peri/ 


\title{
Is there a case for formal inflation targeting in sub-Saharan Africa? ${ }^{i}$
}

\author{
James Heintz ${ }^{\text {ii }}$ \\ and \\ Léonce Ndikumana ${ }^{\text {iii }}$
}

February 2010

\begin{abstract}
This paper examines the question of whether inflation targeting monetary policy is an appropriate framework for sub-Saharan African countries. The paper presents an overview of inflation targeting, reviews the justification for the regime, and summarizes some major critiques. Monetary policy responses to inflation depend on the source of inflationary pressures. Therefore, the determinants of inflation in African countries are investigated, using dynamic panel data, and the implications for inflation targeting are discussed. These issues are examined in greater detail for the two African countries which have formally adopted inflation targeting, South Africa and Ghana. The analysis is placed in the context of the global economic crisis. The paper concludes with a discussion of alternative approaches to monetary policies and the institutional constraints that would need to be addressed to allow central banks to play a stronger developmental role in sub-Saharan African countries.
\end{abstract}

Key words: Sub-Saharan Africa, inflation, development, monetary policy, finance.

JEL Codes: E31, E52, O55, and O11.

\footnotetext{
${ }^{\mathrm{i}}$ This paper was prepared for the Plenary Session at the Biannual Research Workshop of the African Economic Research Consortium (AERC), November 29, 2009 in Nairobi, Kenya. The authors would like to thank Machiko Nissanke for insightful comments and suggestions.

ii James Heintz is Associate Research Professor at the Political Economy Research Institute (PERI) at the University of Massachusetts. He is the corresponding author (jheintz@peri.umass.edu).

iii Léonce Ndikumana is the Director of Research at the African Development Bank and a member of the AERC network (1.ndikumana@afdb.org).
} 


\section{Introduction}

Inflation targeting is increasingly seen as the 'best practice' for central bank policy in many economies around the world, including a growing number of developing countries. To date, inflation targeting has not made inroads into African economies, with only Ghana and South Africa having formally adopted this policy regime. However, as the practice of inflation-targeting spreads, it raises a number of questions for African countries. Is an inflation-targeting regime the right approach to monetary policy, if the long-run goal is to support economic development and to reduce poverty? Can inflation targeting adapt to the structural realities of African economies? What are some of the potential pitfalls to inflation targeting? Are there viable alternatives? This paper grapples with these questions and raises a number of pertinent issues that should be taken into account in choosing the right monetary policy regime for long-run growth and development in Africa.

The issue of inflation targeting as a monetary policy regime has assumed even higher relevance in African countries as they attempt to respond to the impact of the global economic crisis which began to unfold in the second half of 2008. Unlike in previous crises, the majority of African countries entered this crisis from a much stronger footing in terms of macroeconomic stability thanks to efforts undertaken over the past decades to implement painful macroeconomic and trade reforms (AfDB, UNECA, and OECD 2009). These reforms have helped reduce inflation to single digits in most countries, reduced fiscal and current account deficits, and contributed to gradual improvement in the investment climate, a key factor to the resurgence in private capital inflows observed before the crisis. When the crisis hit African economies through its 
second round effects, African governments responded with a combination of measures to sustain domestic demand and support industrial production. Chief among these measures has been the easing of monetary policy through reduction of the policy rate, injection of liquidity in the system and intervention in the foreign exchange markets to influence the value of the national currency (see AfDB 2009a, 2009b; Kasekende, Brixiova, and Ndikumana 2010).

The ability of the central banks to respond swiftly has been critical in the efforts to alleviate the impact of the crisis. Central banks' responses have been guided primarily by pragmatism rather than adherence to any prescribed policy regimes. Even in South Africa, where the inflation rate broke the inflation target range of 3-6 percent to reach double digits over several months, the Reserve Bank and Treasury have responded flexibly with a combination of fiscal stimulus and easing of the monetary policy stance, with an aim of supporting domestic economic activity. The crisis has clearly demonstrated both the powerful role of counter-cyclical policy and the advantages of flexibility in monetary policy in responding to exogenous shocks. This experience must inform any discussion of adequacy of monetary policy regimes and, for that matter, any other macroeconomic policy frameworks in the context of African economies. This paper is an attempt to contribute to this important and timely debate.

The paper is organized as follows. In the next section, we present an overview of inflation targeting, review the justification for this approach to monetary policy, and summarize some of the major critiques. This initial review will not be restricted to subSaharan Africa, but will draw on the existing literature on inflation targeting more broadly. Following this overview, we examine inflation dynamics in sub-Saharan Africa, 
with particular attention to the role of exchange rates, the money supply, interest rates, and supply-side shocks. We present estimates of the determinants of inflation in African countries, using panel data. We then briefly review the experiences of the two subSaharan African countries which have adopted formal inflation targeting - Ghana and South Africa. Following this discussion the paper reflects on the current global crisis and the impact it has had on monetary policy and inflation targets among African countries. The paper concludes with a discussion of possible alternatives to inflation targeting monetary policy, whether such alternatives are viable, and the constraints which may prevent central banks from playing a stronger developmental role.

\section{Inflation targeting: an overview of key issues}

Inflation targeting, as a formal monetary policy regime, was first introduced in New Zealand in 1990 and has since been adopted by numerous countries around the world. Formal inflation targeting is still uncommon in African countries, with only South Africa and Ghana having officially adopted the framework at the current time. Although many African countries have inflation targets, they have not implemented a policy of formal inflation targeting. Inflation targeting involves a declaration of an inflation target by the central bank - the target is most commonly a narrow range of inflation rates, e.g., 4-6 percent. The central bank then uses monetary tools, often a policy interest rate, in an attempt to keep inflation within the targeted range. The inflation targeting framework stresses increased accountability of the central bank; the central bank must evaluate its performance in meeting the target and publicly disclose the reasons for any deviation. In some cases, the adoption of formal inflation targeting has also involved institutional and 
legal changes which increase the independence of the central bank (Epstein and Yeldan, 2008).

If inflation targets were strictly adhered to, inflation targeting would represent a form of rules-based central banking, in which the scope for discretion is limited. A common justification for limiting the discretionary scope of central banking is that policy makers may, in their attempt to reach short-run objectives, increase inflation above a socially optimal level. The literature on the dynamic inconsistency of monetary policy, first advanced by Kydland and Prescott (1977), represents an influential theoretical expression of this argument: individuals rationally adapt their expectations in response to discretionary changes in monetary policy, eliminating any long-run impact on the real economy. In this framework, rules are preferable, since they eliminate the possibility that policy makers will respond erroneously to short-run incentives to boost growth or employment above a long-run equilibrium level. A crucial assumption is that individuals can distinguish monetary responses (due to central bank policy) from other economic factors (e.g., inflation due to supply-side shocks) in forming their expectations.

In practice, inflation targeting is often not strictly rules-based, and has been referred to as a policy of 'constrained discretion' or as a monetary policy 'framework' (King, 2005; Bernanke et al., 1999). Effectively, this means that the targets represent rules that can be broken, but with a heighten degree of transparency and accountability. When inflation targeting central banks fail to meet the target, they must explain what happened. There is often a gap between the theory and the practice of inflation targeting, caused by external factors and unexpected changes in the macroeconomic environment. 
Expectations play a central role in the motivation for inflation targeting policies. The central idea is that individual expectations will adapt to the targets announced by the central bank. The hope is that these expectations will then be incorporated into contracts, pricing practices, and collective bargaining agreements. These changes in expectations and forward-looking institutional arrangements link the inertial component of inflation (i.e., inflationary pressures derived from previous inflation rates) to the inflation target. Unlike the use of monetary tools to manage inflation, which often impose real economic costs from higher real interest rates or slower credit growth, the change in inertial inflation would not involve similar costs. Therefore, it is frequently argued that formal inflation targeting allows inflation to be controlled at lower cost than other approaches to monetary policy that focus on reducing inflation. Put another way, inflation targeting is said to reduce the 'sacrifice ratio' - the amount of output or employment which must be forgone to reduce inflation by a certain amount.

Based on available evidence, it is not evident that inflation targeting significantly reduces the sacrifice ratio or improves the performance of the real economy (Ball and Sheridan, 2005; Bernanke et al., 1999; Epstein, 2008). There is some evidence that countries that have adopted inflation targeting have experienced reductions in inflation, lower volatility of inflation, and a reduced degree of exchange rate pass-through (Gonçalves and Salles, 2008; Mishkin and Schmidt-Hebbel, 2007; IMF, 2005). However, these results are sensitive to the controls used to ascertain the impact of inflation targeting and are strongest when inflation-targeting countries are compared to their own pretargeting experience (Mishkin and Schmidt-Hebbel, 2007). Comparing the pre-targeting period with the post-targeting period may not capture the impact of inflation targeting per 
se, but rather a re-orientation of monetary policy towards lowering inflation (which could be achieved with or without inflation targeting). Comparisons between inflation-targeting countries and non-targeting countries are weaker and, again, depend on the control group used.

Therefore, whether inflation targeting actually changes expectations in a way which reduces the cost of lowing inflation remains uncertain. ${ }^{4}$ If inflation targeting does not have a significant impact on expectations, inflation targeting may not be overly distinct compared to monetary policy which simply attempts to reduce inflation, or sustain inflation at low levels. The central banks in many African countries have specific inflation targets in their policy statements, PRSPs, or national development strategies (e.g., 5 percent being common at the present time). These inflation targets differ from formal inflation targeting in that the targets are not accompanied by formal processes for holding the central bank accountable for reaching the target in an effort to influence expectations.

Another justification for inflation targeting is that every economy needs a 'nominal anchor' which can serve as the basis for making economic decisions (Bernanke et al., 1999). Without an idea of what the average price level in an economy is (and will likely be in the future), economic actors cannot accurately discern relative price

\footnotetext{
4 Bernanke et al. (1999) present evidence that inflation expectations have adjusted in some countries, but the adjustments have been gradual due to significant inertia. However, the benefits - in terms of lower sacrifice ratios - were not evident. Ball and Sheridan (2005) present evidence suggesting that there is no evidence that inflation targeting raises economic growth. While inflation targeters may experience lower inflation, including inflationary responses to shocks (e.g., Mishkin and Schmidt-Hebbel, 2007; IMF, 2005; Gonçalves and Salles, 2008), the impact on the long-run performance of the real economy remains unclear. Mishkin and Schmidt-Hebbel (2007) present evidence that the adoption of inflation targeting may reduce an indicator of the combined volatility of output and inflation, but this does not imply that inflation targeting improves average growth performance. Gonçalves and Salles (2008) also present evidence that inflation-targeting countries have lower growth volatility relative to a selected group of non-targeters, but the sample is small (36 observations), the results will be sensitive to large outliers, and there is no clear justification for the selection of countries included in the non-targeting control group.
} 
movements and may make errors in allocating resources in response to changing prices. Historically, devices such as the gold standard provided this anchor. In the absence of a similar absolute standard, monetary policy must play this role, and inflation targeting represents one option for establishing a nominal anchor for a market economy.

The fact that the true economic costs of inflation targeting remain uncertain raises important challenges for policy evaluation. Ideally, we would want to weigh the costs of inflation targeting against its benefits and thereby determine whether the adoption of formal inflation targeting is desirable. There is nothing intrinsically desirable about inflation. If countries in sub-Saharan African countries could experience rapid growth and development with 2 percent inflation or the same rate of development with 15 percent inflation, it would be rational to choose the lower inflation rate. However, if maintaining a 2 percent rate of inflation slows the rate of economic development, then it is unclear whether keeping inflation at that level is the best option.

A common argument for conducting monetary policy so as to keep inflation very low (e.g., in the lower single digits) is that inflation is harmful to long-run growth. There are several reasons for this: inflation can raise transactions costs and may contribute to uncertainty about the future. ${ }^{5}$ However, there is no consensus in the literature that maintaining rates of inflation at a typical inflation targeting level (e.g., around 5 percent) necessarily leads to faster growth.

One early study of the relationship between inflation and growth across 127 countries found that growth rates declined only when inflation rates moved beyond 20-25 percent and that growth increased as inflation rose up to the 15-20 percent range (Bruno,

\footnotetext{
5 The idea of 'menu costs,' such as that advanced by Mankiw (1985), represents the kind of transactions costs associated with inflation.
} 
1995). Similarly, Bruno and Easterly (1998) reported that the negative relationship clearly manifests itself only when inflation exceeds 40 percent. These early estimates were based on combined data across all countries. However, the threshold at which inflation reduces growth appears to vary between developed and developing countries. Khan and Senhadji (2001) identify the threshold point at which inflation reduces economic growth at 1 to 3 percent for developed economies, but the threshold point for developing countries is between 11 and 12 percent. Pollin and Zhu (2006) find that higher inflation is associated with moderate gains in GDP growth up to 15-18 percent inflation, after which growth begins to decline. The results are more robust in developing countries relative to developed economies. Some researchers have found that the threshold at which inflation reduces growth is in the single-digits (Ghosh and Phillips, 1998; Burdekin, Denzau, Keil, Sitthiyot, and Willett, 2004). ${ }^{6}$

What can we conclude from these studies? There is broad consensus that rapid rates of inflation will have a negative impact on growth, and this turning point will most likely be reached once inflation exceeds 15 to 20 percent. Only a few studies show that reducing inflation down to the level typically adopted in inflation targeting regimes will contribute to stronger growth. Other studies suggest that keeping inflation in this range actually leads to slower growth. At best, the benefits of maintaining inflation in the lower

\footnotetext{
6 Hodge (2006) presents evidence that, controlling for fixed investment, inflation has a negative impact on growth in South Africa. However, he uses a linear model which does not allow for threshold effects. Therefore, we cannot conclude that reducing inflation to the inflation targeting range of 3 to 6 percent will necessarily be beneficial to South Africa, holding other factors constant. Hadjimichael, et al. (1995) found a negative impact of inflation (and, surprisingly, a positive effect of the standard deviation of inflation) on growth in a cross-country study of African economies over a short time period, 1986-1992, and without controlling of unobserved country-specific effects (apart from broad country groupings). Again - the study did not attempt to model the non-linearities in this relationship, and cannot shed light on the threshold effects discussed here.
} 
single digits are uncertain and there is a possibility it may slow the process of development.

In some contexts, finding a negative relationship between inflation and growth should not be surprising. This is not because inflation causes growth to slow down, but rather because exogenous shocks to the economy (e.g., external price shocks or supplyside shocks) affect both growth and inflation. A crop failure can simultaneously raise domestic food prices and slow growth. For countries in which agriculture accounts for a sizeable portion of GDP and food constitutes a significant part of the consumption bundle on which measures of inflation are based - as in the case for many African countries such a shock will lower growth and raise inflation, potentially by a sizeable amount. Such shocks are often assumed to be transitory, with few long-run consequences. However, the possibility of hysteresis should not be ignored - short-run shocks may have long-run consequences. An economic shock may have a dramatic impact on assets and investments which could have implications for the supply-side of the economy for years to come. Most of the studies of the impact of inflation on growth do not take these dynamics into account.

Many studies of the impact of inflation on growth also do not adequately capture the costs of controlling inflation. For example, many studies include fixed investment (or the capital stock) as one of the controls in the growth equation, along with inflation and other explanatory variables. The impact of inflation is estimated holding fixed investment constant. However, maintaining low rates of inflation often involves changes in other prices in the economy, e.g., higher real interest rates or an appreciating real exchange rate. These price changes directly impact investment decisions and, as a consequence, 
long-run growth. However, this effect will not be captured if investment is held constant. If these relationships are present, then the point at which inflation negatively impacts growth is likely to be underestimated.

This leads us to one of the principal critiques of inflation targeting: this approach to monetary policy presumes that maintaining low inflation (often very low rates of inflation) will necessarily contribute to faster growth and more rapid development. For this argument to be justified, we must be confident that all the economic costs of inflation targeting are adequately captured in the analysis. For example, in many developing countries and emerging markets, maintaining very low inflation rates requires significant increases in the real interest rate (e.g., Epstein, 2008). High real interest rates may have negative consequences for growth and development. Accurately measuring all these effects is not a simple task.

Another channel through which inflation targeting may negatively affect the trajectory of development is through the real exchange rate and financial volatility (Galindo and Ros, 2008; Barbosa-Filho, 2008; Cordero, 2008). In economies with relatively unrestricted capital mobility and reasonably developed capital markets, the high interest rates associated with inflation targeting often attract inflows of short-term portfolio investment. Such capital flows can lead to an appreciation of the real exchange rate, hurting exports and facilitating import penetration. Tradable sectors will be adversely affected by such an appreciation, leading to a reallocation of resources to the non-tradable sector. If productivity levels, on average, are lower in the non-tradable sector, the outcome will be slower growth and delayed industrialization. In addition, the accumulation of stocks of short-term capital increases the risk of financial fragility. A 
rapid reversal of these flows can lead to a collapse of the currency and, in turn, a broader economic crisis.

Finally, inflation targeting must be flexible enough to respond differently, depending on the source of inflation. As noted above, supply-side shocks may simultaneously reduce growth and raise inflation. Tightening monetary policy in response to this kind of shock may make the situation worse (as has been noted by Friedman and Kuttner, 1996). Strict inflation targeting introduces a pro-cyclical bias into monetary policy for countries in which supply-side inflation is commonplace. The degree of this bias will depend on the relative importance of supply-side factors in determining inflation and the amount of discretion monetary authorities are allowed.

None of these critiques of inflation targeting imply that inflation does not matter. However, they do suggest that central banks should have multiple objectives and a variety of policy instruments at their disposal to meet those objectives. We can offer a further caution here, given the topic of this paper: inflation targeting policies have been primarily developed and implemented in high-income economies. Increasingly, the framework is being applied to middle-income countries and emerging markets including South Africa. However, the existing models of inflation targeting have not been adapted to the structural realities of low-income countries, including most African economies, despite Ghana's recent adoption of the framework. Therefore, it is worth examining the issues that arise when we consider inflation targeting monetary policy in the context of sub-Saharan African countries. 


\section{Inflation dynamics in sub-Saharan African countries}

Any evaluation of the promises and pitfalls of inflation targeting in sub-Saharan African countries must consider the nature of inflation and its dynamics. The factors that contribute to inflation, and their relative importance, differ from economy to economy and depend on institutional arrangements and structural realities.

In panel data studies of inflation dynamics across sub-Saharan African countries, increases in the growth rate of the money supply, or, alternatively, the gap between money supply and estimated money demand, has been shown to contribute to inflation (Thornton, 2008; Barnichon and Peiris, 2008). However, Thornton (2008) presents findings that suggest that the money supply is significantly more important for explaining inflation dynamics in high-inflation countries than in low-inflation countries. These studies indicate that supply-side factors play a role in determining inflation dynamics negative shocks to economic growth or lower estimated values for potential GDP raise inflation rates. $^{7}$

Country-level studies also shed light on sources of inflationary pressures in African countries. For example, in Ghana, the growth rate of the money supply (linked to the financing of public sector debt and an expansion of foreign debt) and structural supply-side factors (including shocks to the agricultural sector) are two common explanations for the persistence of high inflation rates from the 1970s through the 1990s, despite the introduction of stabilization and structural adjustment policies (Aryeetey and Harrigan, 2000). In a study of inflation dynamics in Ethiopia, high rates of inflation have

\footnotetext{
7 Barnichon and Peiris (2008) include an estimate of the output gap (potential output minus actual output) in their regression. The output gap has a positive coefficient, indicating that a fall in potential output will increase inflation. They also show that changes in rainfall directly affect inflation - another supply-side factor.
} 
been linked to agricultural supply shocks and strong inertial dynamics (Loening, Durevall, Birru, 2009). Others have documented the importance of exchange rate passthrough and the price of imports in influencing inflationary dynamics. For example, Oladipo (2007) shows that there is significant, albeit imperfect, pass-through for a variety of products in Nigeria. Therefore, changes in the nominal exchange rate will impact inflation. Nell (2004) presents evidence suggesting that inflation dynamics in South Africa have been influenced by imported inflation, particularly after 1987. The importance of exchange rate pass-through suggests that inflation dynamics would differ in countries with a fixed exchange rate regime (e.g. the CFA countries) relative to countries with more flexible exchange rates.

The literature on inflation dynamics in sub-Saharan African countries demonstrates that there are multiple factors that influence inflation. The domestic money supply can affect average prices with changes in the money supply coming from policy decisions (i.e., deliberate choices taken by the central bank) or from other sources (i.e., financial inflows linked to capital, external debt, or transfers which enter the domestic money supply). The nominal exchange rate and imported inflation is a significant factor. In countries in which foreign exchange reserves are relatively low, demand for foreign exchange to finance imports can lead to a depreciation of the nominal exchange rate and introduce inflationary pressures. External price shocks - e.g., fluctuations in global energy prices - play a role, as do domestic supply-side shocks. Finally, inflation inertia the impact of past inflation on future prices - appears to be important.

Studies of inflation dynamics in African countries tend to focus on a subset of these factors when exploring the determinants of inflation. Here we examine a broader 
range of variables which capture, to some extent, these different contributions to inflation. The reason for this exercise is straight-forward: an evaluation of inflation targeting monetary policy must consider the factors which contribute to inflation in order to reach an informed conclusion. Inflation targeting has distinct implications for the economy, depending on the source of the inflation.

We assemble a panel dataset for sub-Saharan African countries covering the period 1975-2007. In our initial estimates, we focus on 12 African countries for which we have relatively complete data (Botswana, Cameroon, Chad, Gabon, The Gambia, Kenya, Malawi, Lesotho, Mauritius, South Africa, Swaziland, and Zimbabwe). This group spans the broad spectrum of country categories, notably middle-income and low incomecountries, as well as resource-rich and resource-scarce countries. Moreover, we will consider a broader selection of 29 countries later in the analysis. The panel is unbalanced, but we impose the restriction that a country must have a minimum of 20 contiguous years of observations in all variables to be included. The full set of variables for the initial 12country panel are: the annual inflation rate (based on the consumer price index), the growth rate of the money supply (M2), the percent change in the food production index (to capture agricultural supply-side shocks), the percentage change in the nominal exchange rate, the percentage change in the terms of trade index, the percentage change in the nominal lending rate, and the change in government consumption expenditures as a percentage of GDP. All data come from the World Bank's African Development Indicators. Table 1 summarizes the variables included in the analysis. 
Table 1. Description of variables.

\begin{tabular}{|l|l|l|}
\hline Variable & Description & Source \\
\hline inf $_{\mathrm{t}}$ & $\begin{array}{l}\text { Annual inflation rate based on national } \\
\text { CPI }\end{array}$ & $\begin{array}{l}\text { African Development Indicators, } \\
\text { 2008-9. }\end{array}$ \\
\hline $\mathrm{gdp}_{\mathrm{t}}$ & Annual growth rate of real GDP & $\begin{array}{l}\text { African Development Indicators, } \\
\text { 2008-9. }\end{array}$ \\
\hline $\mathrm{m} \mathrm{t}_{\mathrm{t}}$ & $\begin{array}{l}\text { Annual growth rate of the money supply } \\
(\mathrm{M} 2)\end{array}$ & $\begin{array}{l}\text { African Development Indicators, } \\
\text { 2008-9. }\end{array}$ \\
\hline $\mathrm{xch}_{\mathrm{t}}$ & $\begin{array}{l}\text { Natural logarithm of nominal exchange } \\
\text { rate(per \$US), first difference }\end{array}$ & $\begin{array}{l}\text { African Development Indicators, } \\
\text { 2008-9. }\end{array}$ \\
\hline $\mathrm{fd}_{\mathrm{t}}$ & $\begin{array}{l}\text { Natural logarithm of food production } \\
\text { index, first difference }\end{array}$ & $\begin{array}{l}\text { African Development Indicators, } \\
\text { 2008-9. }\end{array}$ \\
\hline tot $_{\mathrm{t}}$ & $\begin{array}{l}\text { Natural logarithm of terms of trade } \\
\text { index, first difference }\end{array}$ & $\begin{array}{l}\text { African Development Indicators, } \\
\text { 2008-9. }\end{array}$ \\
\hline int $_{\mathrm{t}}$ & $\begin{array}{l}\text { Natural logarithm of prime lending rate, } \\
\text { first difference }\end{array}$ & $\begin{array}{l}\text { African Development Indicators, } \\
\text { 2008-9. IMF International } \\
\text { Financial Statistics. }\end{array}$ \\
\hline gov $_{\mathrm{t}}$ & $\begin{array}{l}\text { Natural logarithm of government } \\
\text { consumption expenditure as \% of GDP, } \\
\text { first difference }\end{array}$ & $\begin{array}{l}\text { African Development Indicators, } \\
\text { 2008-9. }\end{array}$ \\
\hline
\end{tabular}

A fixed effects model is used in all the estimations of the general form:

$$
\pi_{j t}=\sum_{k=0}^{K} \beta_{k} \mathbf{X}_{j, t-k}+\varepsilon_{j}+\mu_{j t}
$$

in which $\pi_{j t}$ is the inflation rate in time period ' $\mathrm{t}$ ' for country ' $\mathrm{j}$ ', $\beta_{k}$ is a vector of coefficients on the explanatory variables (lagged 'k' periods), $\mathrm{K}$ is a scalar indicating the maximum lag length, $\mathbf{X}_{j t}$ is a matrix of explanatory variables, $\varepsilon_{j}$ is the error component of country ' $\mathrm{j}$ ', and $\mu_{\mathrm{jt}}$ is a stochastic error term. We also estimate a dynamic version of the model which includes lagged endogenous variables on the right-hand side of the equation:

$$
\pi_{j t}=\sum_{l=1}^{L} \alpha_{l} \pi_{j, t-l}+\sum_{k=0}^{K} \beta_{k} \mathbf{X}_{j, t-k}+\varepsilon_{j}+\mu_{j t}
$$


In the above expression, $\alpha_{l}$ is the coefficient on the inflation rate, lagged 1 periods, $\mathrm{L}$ indicates the lag length for the endogenous regressor, and $\mathrm{K}$ is the lag length for the other explanatory variables.

In the dynamic specification of the model, with lagged inflation rates on the right hand side, the lagged endogenous variable is correlated with the error component, $\varepsilon_{\mathrm{j}}$. If OLS is used to estimate the model, the endogeneity of the lagged regressor could bias the estimates. ${ }^{8}$ Therefore, we estimate the model using both OLS and instrumental variable techniques (two-stage least squares). We need to identify an instrument that is correlated with the lagged regressor, but is not correlated with the error term. We propose using lagged values of the first differences of the inflation rate. ${ }^{9}$ By taking first differences of the inflation rate, we eliminate the error component term. In the estimates presented here, the inflation rate was lagged only one period (longer lagged structures did not improve the estimates). Therefore, the first difference of the inflation rate lagged two periods was used as an instrument in the IV estimations.

In addition, we have included the growth rate of GDP as an explanatory variable. However, as has already been discussed, inflation rates may have an impact on economic growth. Therefore, we also present estimates in which the growth rate is treated as an endogenous variable. Again, instrumental variable estimation is used, but with a broader

\footnotetext{
8 In the panel data used, the number of cross-sections $(\mathrm{K})$ is relatively fixed, but the time dimension would increase as new data becomes available. The relevant asymptotic properties of the model are those in which $\mathrm{K}$ is fixed but $\mathrm{T} \rightarrow \infty$. As $\mathrm{T}$ becomes larger and larger, the bias associated with the lagged endogenous variable will approach zero.

9 Arellano and Bond (1991) propose a GMM technique for estimation of dynamic panel models. Variations on this approach have been developed. However, these estimators were developed for models in which the number of cross sections is large and the time series dimension is limited. The number of instruments used by the Arellano and Bond estimator increases significantly with $\mathrm{T}$. This can create a problem of an excessive number of instruments. If the instruments are weak, the estimations will be of poor quality and potentially biased. Given that our sample includes a small number of countries (small K) but quite a large number of years (large T), we chose a different approach here in which we are more parsimonious in the number of instruments used and test for the validity of the instruments are applied.
} 
set of instruments. We include three instruments for the GDP growth rate, drawing from the extensive empirical literature on the determinants of growth: the population growth rate, the initial value of real per capita GDP, expressed in \$US, for each decade (1970, 1980, 1990, 2000), and a dummy variable indicating whether the country experienced a drought in any particular year. ${ }^{10}$

The results of this analytical exercise are presented in Table 2 . In all cases, robust White standard errors accounting for the presence of heteroskedasticity are reported. Equation 1 is a simple fixed-effects model, estimated using standard OLS techniques, which does not include lagged inflation on the right-hand side. The growth rate of M2 has a significant impact on inflation as does the nominal exchange rate (in this case, an increase in the exchange rate indicates a depreciation). Note that the money supply and nominal exchange rate are both expressed in annual percentage changes. The sum of the coefficients on the exchange rate variables is larger than the sum of the coefficients on the money supply variables. This would indicate that a 10 percent depreciation of the exchange rate would have a larger impact, holding other factors constant, than a 10 percent increase in the growth rate of the money supply. The results suggest that supply side factors are important - changes in food production, lagged one period, have an impact on current inflation. The sign on the GDP growth rate is negative, but is not statistically significant. The terms of trade index, the prime lending rate, and government consumption spending are all insignificant.

\footnotetext{
10 As pointed out already, a drought can affect domestic prices, raising some question as to whether it would make a good instrument in this case. We assume that a drought would impact inflation through its impact on the supply-side of the economy - that is, by affecting GDP growth - and therefore helps identify the supply-side impact on inflation.
} 
Table 2. Determinants of inflation in African countries, coefficient estimates of fixed effects empirical model (1975-2007), unless otherwise indicated, robust standard errors are presented in parenthesis.

\begin{tabular}{|c|c|c|c|c|c|c|}
\hline & $\begin{array}{l}(1) \\
\text { OLS }\end{array}$ & $\begin{array}{c}(2) \\
\text { OLS }\end{array}$ & $\begin{array}{l}\text { (3) } \\
\text { IV }\end{array}$ & $\begin{array}{l}\text { (4) } \\
\text { IV }\end{array}$ & $\begin{array}{l}(5) \\
\text { IV }\end{array}$ & $\begin{array}{l}\text { (6) } \\
\text { IV }\end{array}$ \\
\hline $\inf _{t-1}$ & -- & $\begin{array}{c}0.630^{*} \\
(0.032)\end{array}$ & $\begin{array}{c}0.636^{*} \\
(0.193)\end{array}$ & $\begin{array}{c}0.737^{*} \\
(0.161)\end{array}$ & $\begin{array}{c}0.747^{*} \\
(0.165)\end{array}$ & $\begin{array}{c}0.672^{*} \\
(0.249)\end{array}$ \\
\hline $\operatorname{gdp}_{t}$ & $\begin{array}{l}-0.385 \\
(0.416)\end{array}$ & $\begin{array}{l}-0.352 \\
(0.387)\end{array}$ & $\begin{array}{l}-0.331 \\
(0.242)\end{array}$ & $\begin{array}{c}-1.117^{* *} \\
(0.672)\end{array}$ & $\begin{array}{c}-1.114^{* *} \\
(0.686)\end{array}$ & $\begin{array}{l}-1.047 \\
(0.736)\end{array}$ \\
\hline $\mathrm{m} 2_{\mathrm{t}}$ & $\begin{array}{c}0.051^{*} \\
(0.007)\end{array}$ & $\begin{array}{c}0.031^{*} \\
(0.005)\end{array}$ & $\begin{array}{c}0.032 \\
(0.023)\end{array}$ & $\begin{array}{c}0.033 \\
(0.024)\end{array}$ & $\begin{array}{c}0.033 \\
(0.024)\end{array}$ & $\begin{array}{c}0.043 \\
(0.032)\end{array}$ \\
\hline $\mathrm{m} 2_{\mathrm{t}-1}$ & $\begin{array}{l}0.034^{* *} \\
(0.017)\end{array}$ & $\begin{array}{l}0.023^{*} \\
(0.009)\end{array}$ & $\begin{array}{c}0.023 \\
(0.017)\end{array}$ & $\begin{array}{c}0.017 \\
(0.014)\end{array}$ & $\begin{array}{c}0.017 \\
(0.013)\end{array}$ & $\begin{array}{c}0.023 \\
(0.016)\end{array}$ \\
\hline $\mathrm{xch}_{\mathrm{t}}$ & $\begin{array}{c}0.937^{*} \\
(0.310)\end{array}$ & $\begin{array}{c}0.721^{*} \\
(0.214)\end{array}$ & $\begin{array}{c}0.720^{*} \\
(0.282)\end{array}$ & $\begin{array}{c}0.658^{*} \\
(0.245)\end{array}$ & $\begin{array}{c}0.653^{*} \\
(0.245)\end{array}$ & $\begin{array}{c}0.541^{*} \\
(0.205)\end{array}$ \\
\hline $\mathrm{xch}_{\mathrm{t}-1}$ & $\begin{array}{l}0.200^{*} \\
(0.052)\end{array}$ & $\begin{array}{l}-0.268 \\
(0.220)\end{array}$ & $\begin{array}{c}-0.273^{* *} \\
(0.147)\end{array}$ & $\begin{array}{l}-0.353^{*} \\
(0.156)\end{array}$ & $\begin{array}{l}-0.358^{*} \\
(0.159)\end{array}$ & $\begin{array}{l}-0.135 \\
(0.185)\end{array}$ \\
\hline $\mathrm{xch}_{\mathrm{t}-2}$ & $\begin{array}{c}0.261^{*} \\
(0.080)\end{array}$ & $\begin{array}{c}0.162 \\
(0.133) \\
\end{array}$ & $\begin{array}{l}0.163^{* *} \\
(0.087)\end{array}$ & $\begin{array}{c}0.133 \\
(0.099) \\
\end{array}$ & $\begin{array}{c}0.134 \\
(0.101) \\
\end{array}$ & $\begin{array}{c}0.051 \\
(0.105) \\
\end{array}$ \\
\hline $\mathrm{fd}_{\mathrm{t}-1}$ & $\begin{array}{l}-0.142^{*} \\
(0.061)\end{array}$ & $\begin{array}{l}-0.114^{* *} \\
(0.055)\end{array}$ & $\begin{array}{c}-0.117^{* *} \\
(0.064)\end{array}$ & $\begin{array}{l}-0.145^{*} \\
(0.073) \\
\end{array}$ & $\begin{array}{l}-0.155^{*} \\
(0.080)\end{array}$ & $\begin{array}{c}-0.162^{* * *} \\
(0.093)\end{array}$ \\
\hline tot $_{t}$ & $\begin{array}{c}-0.005 \\
(0.081)\end{array}$ & $\begin{array}{l}0.016 \\
(0.21)\end{array}$ & $\begin{array}{c}0.023 \\
(0.059) \\
\end{array}$ & $\begin{array}{c}0.033 \\
(0.065) \\
\end{array}$ & --- & --- \\
\hline int $_{t-1}$ & $\begin{array}{l}-0.087 \\
(0.123) \\
\end{array}$ & $\begin{array}{c}-0.138 \\
(0.095) \\
\end{array}$ & $\begin{array}{c}-0.140^{* *} \\
(0.076)\end{array}$ & $\begin{array}{l}-0.148^{*} \\
(0.074)\end{array}$ & $\begin{array}{l}-0.152^{*} \\
(0.075)\end{array}$ & $\begin{array}{l}-0.181^{*} \\
(0.082)\end{array}$ \\
\hline $\operatorname{gov}_{t-1}$ & $\begin{array}{l}9.145 \\
(5.34)\end{array}$ & $\begin{array}{l}8.224 \\
(7.31) \\
\end{array}$ & $\begin{array}{c}9.384 \\
(6.392) \\
\end{array}$ & $\begin{array}{l}7.021 \\
(7.55)\end{array}$ & --- & --- \\
\hline Constant & & $\begin{array}{c}0.960 \\
(0.802)\end{array}$ & --- & --- & --- & --- \\
\hline $\begin{array}{l}\text { Under- } \\
\text { Identification }\end{array}$ & --- & --- & $\begin{array}{c}23.32 \\
(p<0.01)\end{array}$ & $\begin{array}{c}22.36 \\
(p<0.01)\end{array}$ & $\begin{array}{c}23.01 \\
(p<0.01)\end{array}$ & $\begin{array}{c}25.27 \\
(p<0.01)\end{array}$ \\
\hline Hansen J stat & --- & --- & --- & $\begin{array}{c}2.49 \\
(\mathrm{p}=0.29)\end{array}$ & $\begin{array}{c}2.42 \\
(\mathrm{p}=0.30)\end{array}$ & $\begin{array}{c}0.817 \\
(\mathrm{p}=0.66)\end{array}$ \\
\hline Countries & 12 & 12 & 12 & 12 & 12 & 16 \\
\hline $\mathrm{N}$ & 321 & 319 & 313 & 313 & 313 & 412 \\
\hline $\mathrm{R}^{2}$ & 0.75 & 0.84 & 0.80 & 0.79 & 0.79 & 0.69 \\
\hline
\end{tabular}

Notes: ${ }^{*}$ signifies statistical significance at the $5 \%$ level. ${ }^{* *}$ signifies significance at the $10 \%$ level.

In Equation 3, the first differences of the inflation rate, lagged two periods, was used as an instrument for the lagged inflation rate (the estimated model is exactly identified). In Equations 4 to 6, the lagged inflation rate and the gdp growth rate are both assumed endogenous. The instruments used to estimate these equations were the two-period lag of the first difference of the inflation rate, the population growth rate, the initial gdp (in real \$US) at the start of each decade, and a dummy variable indicating whether the country experienced a drought in that year.

Equation 2 presents OLS estimates of the model when the lagged inflation rate is included as an explanatory variable. The strong positive coefficient on the lagged endogenous variable suggests that inertial inflation is an important phenomenon in the 
African countries included in this analysis. The results are broadly similar to those obtained in Equation (1) - money supply and the nominal exchange rate are both significant, with the sum of the coefficients on the exchange rate variables still larger than those on the money supply growth rates. In addition, supply-side shocks, in terms of food production, remain important.

However, as we have noted, using OLS to estimate a dynamic panel model may yield biased coefficients due to the endogeneity of the lagged regressor. Therefore, Equation 3 presents estimates obtained using the lagged first differences of the inflation rate as an instrument. A number of changes in the results can be observed. The coefficients on the money supply variables are of the same magnitude as in Equation 1, but they are not statistically significant. However, Wald tests of the sum of the coefficients indicate that the total effect is significantly different from zero (with a pvalue of 0.08 ). The nominal exchange rate retains its statistical significance and the sum of the coefficients is still statistically different from zero $(p$-value $=0.04)$ and larger in magnitude than the sum of the coefficients on the money supply variables. The coefficient on the prime lending rate is also significantly negative. ${ }^{11}$

Equation (4) presents instrumental variable estimates when the GDP growth rate is treated as endogenous. The coefficient on GDP growth remains negative, but becomes statistically significant. This suggests that instrumental variable estimation is needed to identify general supply-side effects. Lagged food production shocks are still treated separately and are significant (the separate treatment is important because of the importance of agriculture in most of the countries analyzed here and the importance of

11 The impact of nominal interest rates on inflation is ambiguous. If interest payments are a large share of production costs and mark-up pricing is practiced, higher nominal interest rates may be associated with higher prices. However, if higher interest rates restrict demand, a negative impact would be observed. 
food prices in measurements of inflation). The coefficient on the lagged inflation rate is somewhat higher than in other estimates, indicating that inertial effects remain important. Finally, the coefficients on the money supply, the nominal exchange rate, and the prime lending rate are similar to Equation 3.

The use of instrumental variable estimation techniques raises questions about the validity of the instruments used. We present two tests of instrument validity in Table 2 . We reject the Anderson LM test statistic of underidentification, indicating that the instruments identify the model. The Hansen J test of overidentifying restrictions fails to reject the null hypothesis, suggesting that our instruments are not correlated with the error term and have been correctly excluded from the specification. These two tests suggest that our instrument set is reasonably valid.

Throughout all these estimates, the coefficients on government consumption spending and the terms of trade index have not been significant. Equation 5 presents estimates when these two variables are dropped. The results are similar to those already described for Equation 4. When we drop the terms of trade index, we are able to include four additional countries in the analysis: Cape Verde, the Central African Republic, Nigeria, and Sierra Leone. Equation 6 presents estimates, paralleling those of Equation 5, but including these four countries. The results are broadly consistent with what has already been discussed: the coefficient on the growth rate of GDP is still negative, but loses some significance with the added countries; the sum of the coefficients on money supply is positive, but small; the sum of the coefficients on the nominal exchange rate is also positive; shocks to food production are significant; and the nominal lending rate has a negative impact on inflation. 
Dropping the interest rate variable allows us to expand the number of countries included in the estimation still further - to a total of $29 .{ }^{12}$ Although dropping the interest rate changes the specification of the model, we do so to test the robustness of the estimates. Equation 7 summarizes the results. The magnitude of inertial inflation increases significantly in these results. The growth rate retains its negative sign, but is not significant. Food production shocks still have a significant impact of inflationary dynamics, suggesting that supply-side factors remain important. Although the sums of the coefficients on the exchange rate and the money supply growth rate remain positive, neither sum is significant at the 10 percent level.

Two countries included in the estimates of Equation 7 - Ghana and Sudan appear to have unusually high levels of inertial inflation, so much so their inclusion affects the estimates for the entire panel. Equation 8 replicates the estimates of Equation 7, but without Ghana and Sudan. The level of inertial inflation drops significantly, and is comparable to other estimates (e.g. Equations 4 and 5). The sums of the coefficients on the money supply growth and exchange rate variables are positive, and significantly different from zero at the 10 percent level. Other coefficient estimates are similar to those obtained in equations that included the interest rate and terms of trade variables. Therefore, we are confident that our estimates are reasonably robust, acknowledging that some countries in sub-Saharan Africa exhibit distinct inflation dynamics.

This empirical exercise is useful in providing a sense of the determinants of inflation in African countries and the relative importance of different variables. However,

12 The full set of countries include Botswana, Burkina Faso, Burundi, Cape Verde, Cameroon, the Central African Republic, Chad, Côte d'Ivoire, Ethiopia, Gabon, The Gambia, Ghana, Kenya, Madagascar, Malawi, Lesotho, Mauritius, Niger, Nigeria, Rwanda, Senegal, Sierra Leone, South Africa, Sudan, Swaziland, Tanzania, Togo, Uganda, and Zimbabwe. Although data is available for the Democratic Republic of the Congo, its inclusion produced unstable estimation results. 
some caveats should be kept in mind. Perhaps most importantly, like most fixed effects analysis, the coefficients are restricted to be identical across countries. This assumption allows us to pool observations and to generate estimates with greater statistical precision. Nevertheless, in formulating monetary policy for any particular country, such an approach is not a substitute for careful analysis of inflation dynamics in the economy in question.

One of the strongest results from this analysis is that exchange rates are important variables to consider in an analysis of inflation dynamics in sub-Saharan African countries. What implications does this have for inflation targeting? If we consider a strict inflation targeting regime with substantial exchange rate pass-through, then policy makers will have to target exchange rates, either explicitly or implicitly, in order to reach the inflation target. To some degree, inflation targeting becomes exchange rate targeting. This introduces tensions between efforts to meet an inflation target and interventions to manage the exchange rate. A recent study of inflation targeting regimes in emerging markets found that inflation-targeting countries are actually pursing a mixed strategy responding to both inflation rates and real exchange rates (Aizenman, Hutchison, and Noy, 2008). This same study found that emerging markets without an inflation targeting regime tended to respond more strongly to the real exchange rate. This raises a number of issues for further investigation: is the exchange rate that is consistent with the inflation target also the exchange rate that is consistent with industrialization and long-run development? If not, is it possible to reconcile an inflation-targeting regime with one that attempts to manage exchange rates to support developmental outcomes? 
The importance of exchange rates also raises concerns about the level of foreign reserves a country should maintain, if it is to consistently meet its inflation target. Epstein and Yeldan (2008) present evidence suggesting that many countries have accumulated larger stocks of foreign exchange reserves after adopting an inflation targeting regime. One explanation is that these reserves may be needed in order to defend the currency and control inflation if the economic environment changes in a way that could lead to a depreciation. Maintaining excess reserves can be costly, particularly for African countries with a structural dependence on key imported goods. In the context of a global economic crisis like the one which began in 2008, maintaining an adequate stock of foreign reserves becomes even more challenging when prices of exports fall dramatically and capital inflows become scarcer.

Researchers in Latin America raise concerns that inflation targeting has lead to over-valued exchange rates (e.g., Galindo and Ros, 2008; Barbosa-Filho, 2008). In these cases, the high interest rates needed to keep inflation low attract short-term capital inflows which can lead to an appreciation of the real exchange rate. For many subSaharan African countries, with underdeveloped capital markets, these risks may not yet be evident. However, as capital markets deepen and expand, this could become an important issue in the near future. South Africa has confronted the challenge of a reversal in short-term capital flows in the context of an inflation targeting regime. It is important to consider the lessons from this experience when weighing the pros and cons of inflation targeting in other African countries.

In our results, monetary aggregates - specifically the growth rate of M2 - do not have as strong of an impact on inflation as do nominal exchange rates. This does not 
mean that the money supply is unimportant. However, it may indicate that changes in the money supply impact inflation through their influence on other variables. Clearly, the nominal exchange rate is a possible candidate. Increases in the growth rate of the domestic money supply can lead to currency depreciation and, as a result, higher prices for imported goods and for domestic products that can be traded internationally. In this case, the impact of the money supply does not operate through traditional demand-pull mechanisms, in which excess domestic demand relative to limited productive capacity raises prices. Also, as previously mentioned, Thornton (2008) found that the money supply was more important in explaining inflation in African countries with high rates of inflation (e.g., above 30 percent) than in countries with lower rates of inflation. Rapid growth of monetary aggregates explains excessive inflation in sub-Saharan Africa, but is less important in explaining moderate inflation.

The estimates presented here also indicate that supply-side factors play a role in determining inflation. As discussed earlier, strict inflation targeting in the context of supply-side inflation implies that monetary policy will have a pro-cyclical bias. This bias can be minimized if monetary authorities have sufficient discretion in the conduct of monetary policy to modify their reactions based on the source of inflation. For African countries, flexibility in the conduct of monetary policy has often been restricted due to agreements with the International Monetary Fund in the context of the IMF's lending programs. For example, the restrictions associated with the IMF's financial programming model may not always be appropriate for many low-income countries (Easterly, 2002). Therefore, when evaluating policy of inflation targeting, the amount of 'constrained discretion' which will be allowed in practice is an important consideration. 


\section{Experiences with inflation targeting in Africa: South Africa and Ghana}

Two countries in sub-Saharan Africa currently have inflation targeting regimes: South Africa and Ghana. We consider these two cases briefly here. South Africa formally announced that it would adopt inflation targeting in 2000. Therefore, we can examine its record with regard to actual inflation, inflation targets, and other macroeconomic variables over a period of approximately one decade. ${ }^{13}$ Ghana adopted inflation targeting in 2007. Therefore, the time period over which we can examine trends since the advent of inflation targeting is much shorter. Therefore, our discussion of the Ghanaian case will be provisional.

\section{South Africa}

South Africa's target range for inflation is 3 percent to 6 percent. When inflation targeting was introduced in 2000, it was decided that a modified version of the consumer price index - the CPIX - would be used to calculate inflation rates. The CPIX excludes the financing component of housing costs (i.e., mortgage interest payments). The reason for excluding mortgage interest from the CPI is that most South African mortgages are flexible rate mortgages - when the market interest rate rises, so does the mortgage payment. If these dynamics affected the measurement of price inflation, then the central bank could, in theory at least, respond to increases in market interest rates by increasing its policy rate (i.e., the repo rate in South Africa) - that is, the central bank would exacerbate the increase in interest rates. As of January 2009, the practice of maintaining

13 Although South Africa announced that it would begin inflation targeting in 2000, the implementation of the policy effectively began in 2002 . 
separate price indices (the CPI and the CPIX) was discontinued, and the current CPI is defined analogously to the earlier CPIX.

The policy of inflation targeting was announced in February 2000. If we focus on the 36 quarters from the third quarter of 2000 to the second quarter of 2009, average quarterly inflation was within the 3 to 6 percent range for 14 of these quarters. Roughly speaking, the Reserve Bank of South Africa was able to meet its target about half the time since announcing the policy of inflation targeting. The period from the fourth quarter of 2003 to the first quarter of 2007 was the most successful in terms of keeping inflation within the targeted range. This period was also marked by relatively strong economic performance and higher average rates of GDP growth, compared to earlier years in the post-apartheid era.

Figure 1 shows inflation rates (measured as annual rates and based on the CPIX) from the first quarter of 2000 to the second quarter of 2009. The figure also shows trends in the real prime lending rate and an index of the real effective exchange rate over the same period. In terms of inflation trends, we can identify two inflationary periods in the period since the introduction of inflation targeting: the period spanning the second quarter of 2002 to the second quarter of 2003 and the period beginning in the fourth quarter of 2007. 
Figure 1. Inflation rates (CPIX), real prime lending rates, and index of the real exchange rate in South Africa, 2000-2009.

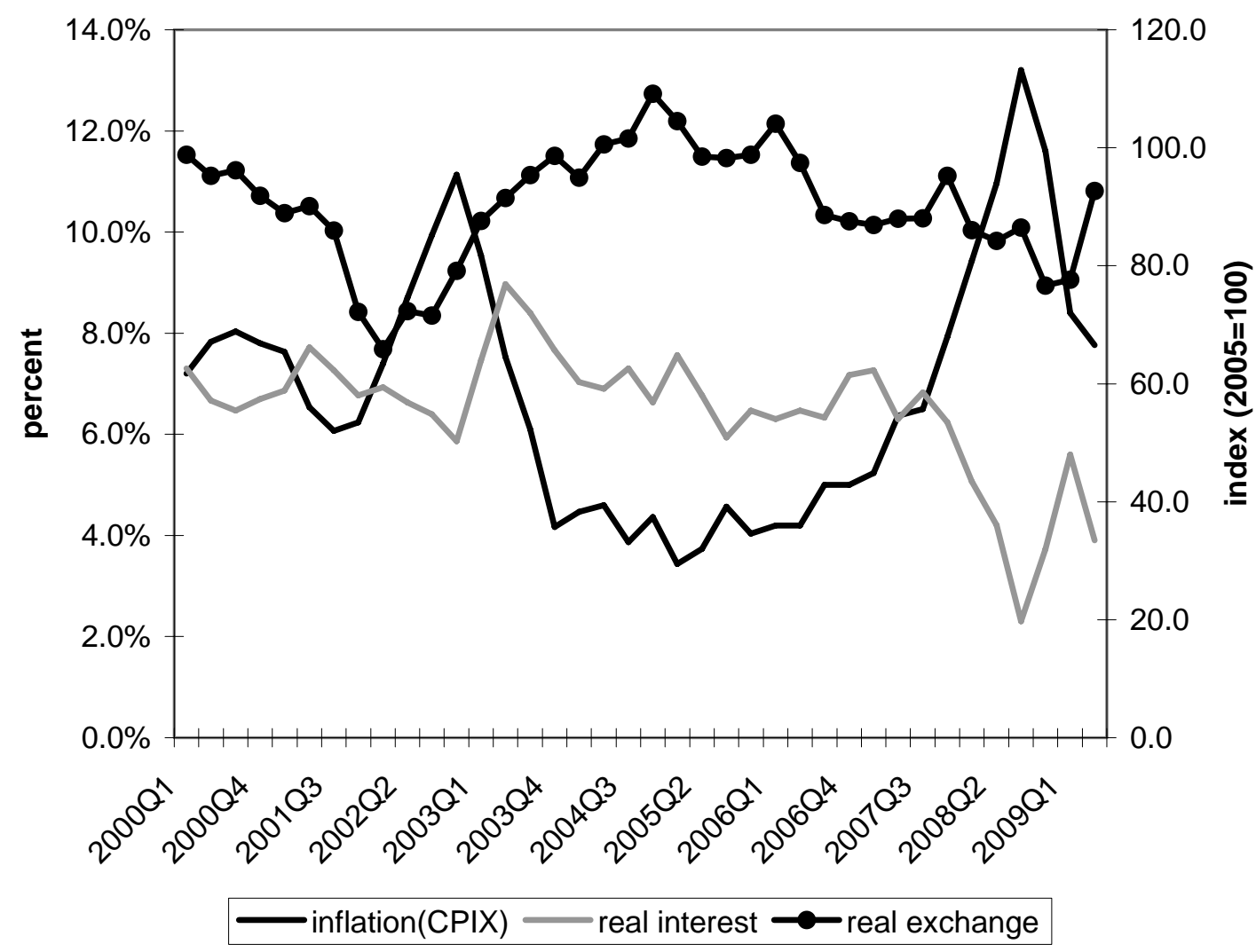

Source: Statistics South Africa and IMF International Financial Statistics.

The first inflationary period corresponded to a rapid depreciation of the rand, linked to a sudden increase in the outflow of short-term capital. The Reserve Bank did not attempt to control this inflationary spike by dramatically increasing real interest rates or by attempting to defend the value of the rand, as had occurred during an earlier inflationary shock (1997-8) caused by a depreciation (Aron and Muellbauer, 2007). The cost of trying to meet the inflation target was judged greater than the benefits of a sizeable intervention. In the second inflationary period, beginning at the end of 2007 , 
increases in global food and energy prices contributed to the highest rates of inflation in the inflation targeting period. Again, real interest rates were not raised in an effort to bring inflation down into the target range.

This suggests that the Reserve Bank of South Africa enjoys a high degree of discretion in terms of which policies to pursue at what time in order to manage inflation. The Medium Term Budget Policy Statement of 2003 states this explicitly, as pointed out by Aron and Muellbauer (2007):

'When the economy is buffeted by a supply-side shock similar to those envisaged by the original escape clause that will take inflation outside of the target range (e.g., an oil price shock, a drought, a natural disaster, or financial contagion affecting the currency), at the subsequent meeting of the MPC [Monetary Policy Committee], the SARB [South African Reserve Bank] will fully inform the public of the nature of the 'shock' ... and the monetary policy response.'

This policy was clearly put into practice during the first decade of inflation targeting in South Africa.

Although the Reserve Bank did not dramatically raise real interest rates or attempt to defend the real exchange rate during these inflationary episodes, it does not mean that the inflation targeting policy imposed few costs on the economy. Real interest rates were not raised in response to an unexpected depreciation or the external price shocks, but, as Figure 1 indicates, they did remain high throughout this period. Studies of the South 
African economy during the inflation targeting period suggest that the benefits in terms of growth and employment may have been greater if interest rates could have been reduced (Epstein, 2008).

Similarly, during the period in which the inflation target was met (roughly 2003 to the beginning of 2007), the index of the real effective exchange rate was higher compared to other quarters (i.e., the real exchange rate appreciated somewhat). We cannot judge from these simple trends whether the rand is at risk of being over-valued as a result of inflation targeting. Indeed, the index of the real effective exchange rate was higher still in several of the years immediately preceding the introduction of inflation targeting - when the Reserve Bank aimed to keep inflation low and more forcefully defended the value of the rand. Nevertheless, an appreciating exchange rate may be cause for concern in that it could reduce export competitiveness and intensify import penetration.

Has the inflation targeting regime in South Africa influenced expectations? This is a difficult question to answer accurately, given the short time frame in which the policy has been in place, the deviations from the inflation targets caused by external shocks and currency depreciation, and the challenge of accurately measuring expectations. A recent study by Rossouw and Padayachee (2009) explored the factors that influence inflation credibility and expectations in South Africa. They found that perceptions of how well the government is able to control inflation are linked to the actual rate of inflation, not a stated inflation target. Their analysis also suggests that expectations may be formed over the long-run. The authors discuss the results of pilot surveys that indicate individuals do not have a strong basis for understanding whether the official inflation rate is an accurate picture of price increases and that 'inflation figures are not generally accepted by a 
representative sample of South Africans as an accurate indication of price increases' ( $\mathrm{p}$. 326). Aron and Muellbauer (2007), in a review of monetary policy in South Africa, cite evidence that inflation expectations, particularly in wage setting, appear to be historically based, and are often not forward-looking. These findings would indicate that expectations among South African will be difficult to shift simply by announcing a target range of inflation.

The same study by Aron and Muellbauer (2007) also documents significant improvements in the transparency of monetary policy after the implementation of inflation targeting. Better transparency, however, does not translate directly into being able to influence expectations or to increase the perceived credibility of central bank policy. The research on expectations and credibility in South Africa raises a number of issues that are relevant for other sub-Saharan African countries. In countries with strong regional variations, is a single inflation target a meaningful indicator of price changes as they are experienced? Are inflation targets meaningful to the people whose expectations the policy is trying to influence?

Since the onset of the global financial and economic crisis, the South African Reserve Bank has shown flexibility and pragmatism in responding to the impact of the crisis (Kasekende, Brixiova, and Ndikumana 2010). Adherence to strict rules under the inflation targeting regime has taken a back seat while the Reserve Bank and Treasury focused on protecting employment and incomes by supporting industry and domestic activity in general. For example, the government adopted a countercyclical fiscal stimulus amounting to R 787 billion (about USD 100 billion) to finance public investment during 2010-12. The Reserve Bank continued to ease monetary policy since 
December 2008, despite the fact that inflation crossed the 6\% upper bound of the inflation targeting range, in an effort to curb the fall in output as the country experienced a recession for the first time in decades. More recently, in a surprise move, the Reserve Bank announced further exchange controls liberalization measures to help curb the appreciation of the rand in order to support export-oriented sectors. The lesson is that it would be counterproductive to enforce a rigid inflation targeting regime in the context of severe exogenous shocks. More generally, any policy regime must be implemented with an adequate dose of flexibility and pragmatism.

\section{Ghana}

Ghana officially adopted inflation targeting in May of 2007. The range of inflation for the initial period of inflation targeting was set at 7 to 9 percent with the target range jointly determined by the Bank of Ghana and the government (Amoah and Mumuni, 2008). The measurement of prices used to target inflation excludes petroleum prices and utilities. The reason for excluding these components is that energy prices can be quite volatile and clearly represents a non-monetary source of inflationary pressures. Excluding the energy component from the CPI does not entirely eliminate the influence of changes in energy prices on inflation. For example, in a study of the component of the CPI for Kenya, using a vector autoregression (VAR) model, Pollin, Githinji, and Heintz (2008) show that a shock to energy prices impacts other components of the CPI. These kinds of interrelationships will likely be evident in other African economies. Although energy shocks cannot be entirely purged from the CPI, excluding these components would mute their influence on the targeted inflation rate. 
The short time period that inflation targeting has been in operation in Ghana makes any evaluation of the policy at this time extremely tentative. In the years immediately preceding the formal adoption of inflation targeting, the Bank of Ghana had attempted to reduce inflation to single digits. Although it is too early to tell how inflation targeting is working, we can examine recent trends in inflation in order to better understand the dynamics of the average price level.

Figure 2 shows quarterly inflation rates (on an annual basis) from the first quarter of 2000 to the second quarter of 2009. During this period, we observe two spikes in inflation - one in late 2000 to the first half of 2001 and a second one in 2003. Several factors contributed to the earlier spike in inflation - higher petroleum prices, slower growth in agricultural production, and a terms of trade shock which put downward pressure on the cedi. The second shock in 2003 can be explained almost entirely by changes in the administrated price policy for petroleum, which led to rapid increases in the domestic price level. ${ }^{14}$ Apart from these two spikes, average inflation rates generally fluctuated between 9 and 15 percent during this period. This is significantly lower than the persistently high rates of inflation which Ghana had experienced in the 1970s, 1980s, and 1990s.

14 These reforms were associated with efforts to deal with the on-going problems of the Tema Oil Refinery, including unsustainable levels of debt. 
Figure 2. Inflation rates (CPI) in Ghana, 2000-2009.

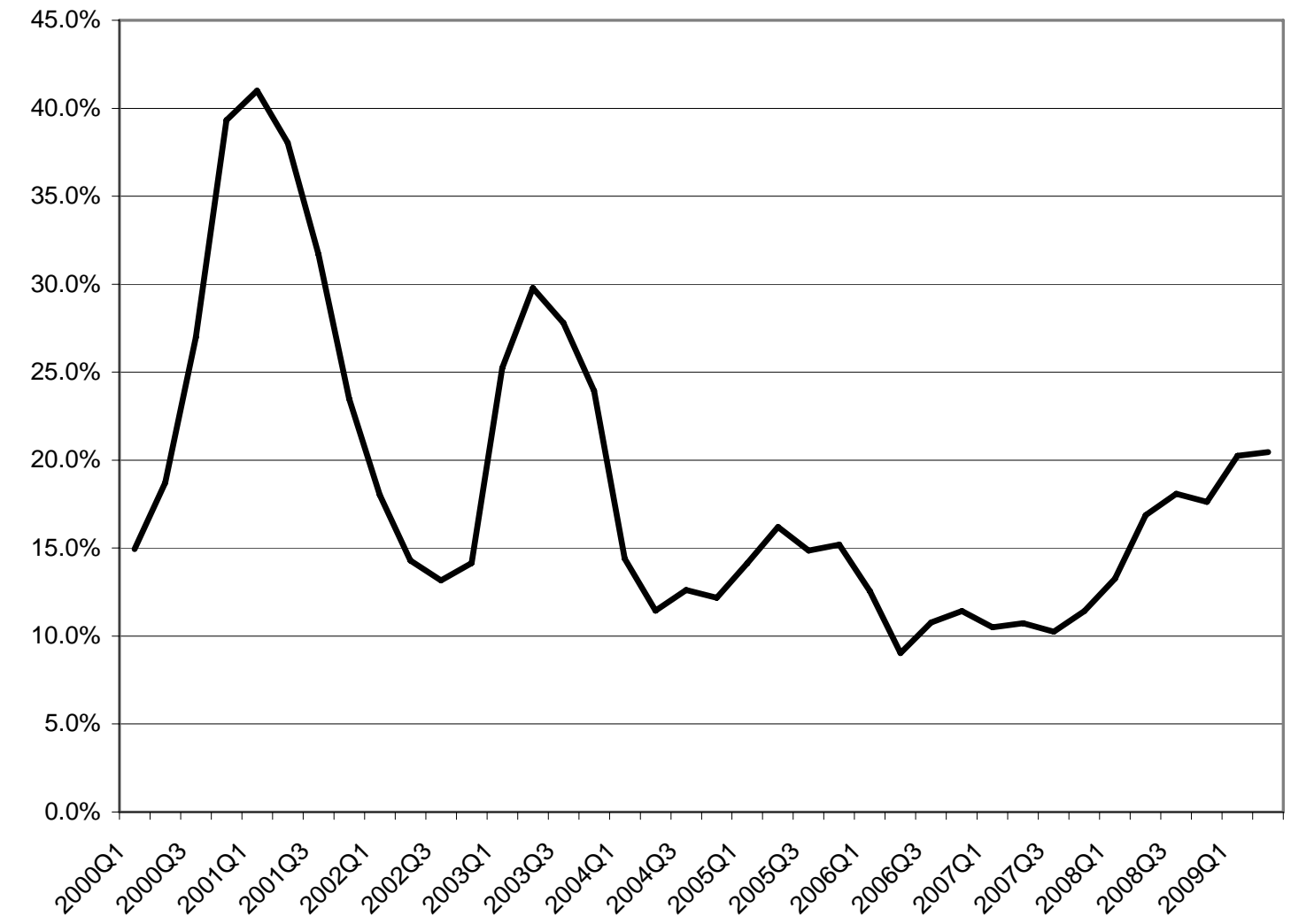

Source: IMF International Financial Statistics.

Ghana introduced inflation targeting at the same time that the pressure on food and fuel prices began to intensify. Beginning in 2007, we see another upward trend in inflation tied to the global rise in energy and food prices. This created a significant challenge for keeping inflation within the target range. When inflation targeting was introduced in 2007, the prime lending rate, determined by the Bank of Ghana, was set at 14.5 percent. The prime rate has been increased since that time in response to growing inflationary pressures and, at the time of this writing, stands at 18.5 percent. During this same time period, the inflation rate doubled, from approximately 10 percent in 2007 to 20 
percent in the first two quarters of 2009. Therefore, the increase in the nominal rate was not proportionate to the increase in inflation (i.e., the real prime rate has declined).

According to Amoah and Mumuni (2008), the processes of transparency and accountability in Ghana differ from those in other inflation targeting countries. When the inflation target is missed, the Bank of Ghana does not produce an open letter or formal report explaining the deviation. However, the Bank of Ghana conducts press releases after monetary policy committee meetings, publishes routine reports, and maintains information on its website. Through these channels the Bank communicates its policy decisions with the public. It is unknown how effective these means of communication are in influencing expectations and enhancing policy credibility.

Ghana's inflation dynamics are strongly influenced by external factors: supplyside shocks, external price shocks (or, in the case of petroleum prices, price shocks linked to domestic policy reform), and changes in the nominal exchange rate. Therefore, many of the concerns discussed earlier in this paper apply to Ghana. Specifically, it will be important for the Bank of Ghana to maintain a high degree of discretion within its inflation targeting framework in order to rationally manage the costs of inflation reduction in the face of external shocks. Indeed, the Bank of Ghana has shown flexibility in managing monetary policy in the context of the crisis. In particular, it has shown great patience in the face of rising inflation, which broke the 20 percent mark over the summer 2009. Thus, monetary policy in the context of the crisis has been guided by discretion and flexibility rather than adherence to strict inflation targeting rules; and this has helped the economy to weather the storm. 


\section{Inflation targeting and the global economic crisis in Africa}

The economic turmoil that engulfed the world's economies towards the end of 2008 has changed the macroeconomic environment fundamentally. The crisis had its origins in the financial markets of the U.S. and other high-income countries. In subSaharan Africa, the crisis has not affected domestic financial and banking sectors to a similar degree. The crisis in Africa is one of declining trade flows, a collapse of commodity prices, reduced access to international private financing (including trade finance), falling government revenues, reductions in remittances, and, to some extent, uncertainty about future commitments of official development assistance (ODA).

In terms of inflationary dynamics, two opposing forces are at work. On the one hand, the steep rise in global prices of 2007 and the first half of 2008 has not continued and has begun to reverse itself. Therefore, external pressures on the price of fuel and food have weakened considerably and, in many countries, have reduced inflationary pressures. On the other hand, many countries with floating exchange rates have experienced some degree of depreciation due to adverse terms of trade movements, declines in financial flows (such as remittances) and falling exports. These changes in nominal exchange rates add to inflationary pressures. The net impact on inflation is uncertain and depends on the structure of individual economies and the exchange rate regime in place.

Although domestic banking sectors in Africa have not come under pressure to the same degree as the financial sectors in many other countries, with the exception of the Nigerian banking sector ${ }^{15}$, the financial crisis has had substantial impact on access to

\footnotetext{
${ }^{15}$ The global credit crunch affected Nigerian banks, which faced difficulties obtaining trade credit lines in the United States and in Europe. In August 2009 the Central Bank of Nigeria (CBN) injected funds into the banking system, when five leading Nigerian banks posted losses from non-performing loans due to
} 
finance throughout the continent. External lines of credit have been closed or limited. For financing of trade (especially imports), borrowers have turned to domestic institutions. Access to sovereign debt has also dried up; governments have had to postpone planned floating of sovereign bonds on the international markets (e.g., Kenya, Tanzania, Uganda; see AfDB 2009c). This creates an increased demand for foreign exchange at a time when foreign exchange earnings are already coming under pressure. The result is further pressure on exchange rates and, as a consequence, additional inflationary impetus.

Although only Ghana and South Africa are implementing inflation targeting, it is useful to consider how inflation targeting would operate in the context of the current crisis. A strict, rules-based inflation targeting regime would attempt to meet its target by raising interest rates and intervening into the foreign exchange market to support the currency. Given that the crisis is already having a significant negative impact on growth and exports, such a reaction would likely worsen the situation in Africa. Moreover, as foreign exchange reserves come under pressure, the cost of defending the domestic currency, by using precious reserves, increases.

However, as we have repeatedly discussed, in practice, inflation targeting often allows a fairly large degree of discretion on the part of monetary policymakers. In South Africa, the repurchase rate (the policy rate) was raised in response to higher rates of inflation, beginning in 2007, but has since come down in 2009. Similarly, in Ghana, as we have noted, the prime lending rate has been raised, but not enough to constitute a hike in real interest rates. Similarly, both countries experienced a depreciation in their nominal exchange rates with the onset of the financial crisis. However, instead of defending the

excessive lending to the energy sector and the burst of the stock market. The sector has stabilized thanks to the swift response by the CBN. 
currency at all costs, both inflation targeting regimes allowed inflation to climb outside of their target ranges (Kasekende, Brixiova, and Ndikumana 2010).

The global economic crisis demonstrates some of the risks attached to inflation targeting and underscores the importance of allowing policymakers sufficient discretion in considering other factors when choosing the best course of action.

\section{Alternatives to inflation targeting?}

Is inflation targeting the right monetary policy for the countries of sub-Saharan Africa to realize the goals of economic development, stability, equitable and rising living standards, and poverty reduction? This paper has argued that a strict inflation targeting regime - a rules-based system with little discretion - is not desirable. Given inflationary dynamics, strict inflation targeting could produce perverse policy responses to production and price shocks. It may also force economies to defend an exchange rate which may not be conducive to long-run growth and diversification of production.

However, many advocates of inflation targeting do not see the approach as constituting a set of inflexible rules. Instead, an inflation targeting regime should be characterized as a framework which allows for 'constrained discretion' - central banks are not free to follow any whim in managing monetary policy, but they also must not be tied to an absolute inflation target that ignores other factors at play. Bernanke, and his coauthors, make this point in a 1999 study of inflation targeting:

'... the idea that monetary policy literally has no other goals than to control inflation would find little support from the public, from central 
bankers, or from monetary economists ... given that governments and central banks do care about production, employment, exchange rates, and other variables besides inflation, treating inflation targeting as an ironclad policy rule could lead to very poor economic outcomes.' (p. 21)

Interpreting inflation targeting as a flexible system for conducting monetary policy, one that takes into account the whole macroeconomic picture, raises an important question. If inflation targeting must take into account a broad spectrum of economic variables when formulating monetary policy, what really differentiates inflation targeting monetary policy from sensible macroeconomic management which incorporates a dual concern for supporting solid performance of the real economy and managing inflation in a sustainable manner?

The distinction is the weight put on inflation in determining any monetary policy response and the presumed role of central bank policy in influencing long-run development. Under an inflation targeting regime, the primary goal of monetary policy is price stability, particularly in the medium- to long-run, and that all other goals must be subordinated to this objective as long as allowance is made for short-run stabilization (Bernanke and Mishkin, 2007). Even here there is some ambiguity over what is meant by 'price stability' (e.g., does maintaining stable inflation at a predictable 10-12 percent constitute price stability or must price stability try to achieve an inflation rate close to zero?) Putting aside the issue of the precise definition of price stability, we can pose another fundamental question: should price stability be the overriding goal of monetary policy in order to support economic development in Africa? 
One alternative to inflation targeting would be to pursue a monetary policy that sees the central bank as an agency of development, one that formulates policy to support the performance of the real economy (Epstein 2007). The primary long-run objective of monetary policy would no longer be price stability, but rather economic growth, employment growth, or some other real outcome that would serve as an indicator of economic development. The monetary policy regime would identify variables that could be targeted in the short-run in order to meet the long-run goals associated with economic development. These short-run targets would complement inflation management goals as the guiding indicators that would direct monetary policy, albeit within a context of 'constrained discretion'. In the analysis associated with inflation-targeting, monetary policy decisions are assumed to have no long-run consequences for output or employment, although short-run trade-offs may exist. However, if we consider that prices such as interest rates and exchange rates do affect investment and can have long-run consequences for development, then real targeting alternatives have the potential to improve economic outcomes.

The growth rate could be one such target. The idea would be to keep policy interest rates within a range that encourages investment and growth and does not lead to excessive inflation. This approach would include a consideration of inflation in the conduct of monetary policy, since the emphasis would be on maintaining positive real interest rates (i.e., excessive rates of inflation would violate this constraint). Bernanke et al. (1999) suggest that a monetary policy regime which targets the nominal GDP growth rate, for example, would operate quite similarly to an inflation targeting regime with 
sufficient discretionary scope to address economic objectives other than inflation. ${ }^{16}$ The difference with the growth target is that it would place more emphasis on real economic performance than would an inflation targeting approach.

Others have argued that instead of real interest rates, central banks should target the real exchange rate, so as to maintain exchange rates at a competitive level, consistent with long-run growth and development (Frenkel and Taylor, 2006). This would mean intervening, as required, in foreign exchange markets to maintain a competitive rate. Again, inflation would be incorporated into policy formulation, since rapid increases in domestic prices would contribute to an appreciation of the real effective exchange rate. Both these alternative targets - the real interest rate and the real exchange rate - attempt to strike a balance between inflation control and variables which have an immediate impact on the performance of the real economy.

Would a 'real-targeting' monetary policy support growth and development in African countries better than an inflation targeting regime? This is difficult to judge for two reasons. First, we do not yet have an accurate picture of all the costs and benefits of inflation targeting in African countries. More research needs to be done. Moreover, an evaluation of inflation targeting should, ideally, be compared to other approaches to monetary policy (Epstein and Yeldan, 2008). Second, and equally important, the success of an alternative to inflation targeting critically depends on the institutional setting in which the policy operates. In the African context, the role of institutions is of the upmost importance.

16 Some of the reasons that Bernanke et al. (1999) give for not focusing on nominal GDP growth as a monetary target is that (1) people may not understand nominal GDP growth in terms of formulating expectations and (2) data on GDP is produced less frequently than data on prices, making it more difficult to formulate immediate responses to changing economic conditions. 
Consider an alternative monetary policy which targets real interest rates at a low and positive level. The idea would be to increase the availability of credit in the banking system and lower its cost, thereby encouraging investment and laying the foundation for long-run growth. However, the success of this strategy rests on a critical assumption: that the banking sector will allocate the additional credit in such a way as to support productive investments. In many African countries, the banking sector is characterized by excess liquidity and a shortage of stable long-term resources for extending credit to finance long-term investment (Sacerdoti, 2005; Mkandawire, 1999; Steele et al., 1997). It is unclear that injecting more liquidity into these banking systems will lead to more investment. The barrier is not monetary policy, but rather the institutional reality of the banking sector in which the incentive structure encourages holding high levels of liquid assets. The reasons for this are various: information asymmetries, lack of capacity in the banking sector itself (particularly in managing small scale loans), the high rates of return on short-term government securities, the erosion and collapse of development finance institutions in many places, and limited information on creditworthiness. Relaxing these constraints requires financial sector reforms - and these reforms may be a prerequisite for introducing an effective, alternative monetary policy.

A second institutional issue involves the mobility of financial capital. In a small open economy with reasonably developed capital markets, targeting interest rates to support economic growth may encourage short-term capital outflows. Such outflows will undermine the success of a 'real-targeting' approach to monetary policy. A similar set of concerns are relevant to policies which aim to maintain a competitive real exchange 
rate. ${ }^{17}$ Under these circumstances, capital management techniques (including capital controls) will be necessary, if an alternative approach to monetary policy is to be successful. As the capital markets of African economies deepen, the importance of managing capital flows to support development and reduce volatility will become increasingly evident.

A regime that targets real exchange rates would encounter other structural challenges. In countries whose exports are dominated by primary commodities, global market prices for these commodities will exert a stronger influence on export performance and economic growth than the domestic exchange rate. If these countries also depend on imported inputs into production, then it is unclear whether attempts to maintain a competitive exchange rate will generate sizeable benefits (relative to countries whose exports are more diversified and include manufactured products). Again - the structure of the economy will influence the success of an alternative approach to monetary policy. This does not imply that the structure should be taken as given, but rather that policy makers would have to pursue structural reforms in concert with a developmental macroeconomic policy.

In African countries, the effectiveness of any approach to monetary policy will depend on these institutional and structural issues. This is true for inflation targeting as well as any of the 'real targeting' alternatives. This issue is often ignored in debates over which approach to monetary policy is the right one. The choice of monetary regime

\footnotetext{
${ }^{17}$ The notion of a 'trilemma' postulates that, in an open economy with free capital mobility, a country cannot simultaneously maintain a fixed exchange rate and an independent monetary policy. Put another way, global integration limits the policy space available for pursing an independent exchange rate or monetary policy. The degree to which the trilemma holds in sub-Saharan Africa will vary from country to country and will depend on the level of financial development and the relative importance of short-term portfolio capital flows.
} 
should not be treated as independent from existing institutions and the imperative of complementary structural reforms. The real question which needs to be asked is which reforms are needed in Africa to allow monetary policy to play a developmental role and, once these reforms are effected, which monetary targets are needed to support long-run development?

\section{Concluding remarks}

This paper has discussed, in some detail, the challenges of implementing an inflation targeting monetary policy in African countries and raised some concerns about the appropriateness of this approach. We summarize a number of observations here:

- A strict rules-based approach to monetary policy, including inflation targeting, is not desirable for the countries of sub-Saharan Africa, given inflation dynamics and structural realities. Any monetary policy should include sufficient scope for discretion to allow the central bank to respond to shocks, especially those originating from the supply side.

- Rapid rates of inflation will undermine economic development. Therefore, management of inflationary pressures is desirable and must be a component of any monetary policy regime. However, the benefits and costs of maintaining very low rates of inflation are unclear. Subordinating other economic goals to inflation reduction is not desirable when the cost of doing so is large. 
- Inflation targeting incorporates critical principles of transparency and accountability in the formulation of monetary policy. These principles are important to maintain within any approach to monetary policy.

- The determinants of inflationary expectations in African economies are not well understood. This is an area for future research.

- The exchange rate is an important macroeconomic variable for African countries. Managing exchange rates is a potentially important policy tool for central banks (this need not imply that fixed exchange rates are desirable, rather that central banks see exchange rate management as a policy instrument).

- The degree to which central banks play a developmental role will be determined by institutional factors, such as the nature of the banking sector, the scope for managing capital flows, and the structure of international trade. The choice of monetary policy regime should not displace the imperative for institutional reform in policy formulation.

With this summary, we return to the question posed in the title of the paper: is there a case for formal inflation targeting in sub-Saharan Africa? The answer to this question is conditional on what the proposed alternatives would be. For example, if we were to compare inflation-targeting, with its emphasis on transparency and accountability, with other monetary policy regimes that lack these characteristics and whose overriding objective is to keep inflation at low levels, then the answer is yes. Inflation targeting represents an improvement on less transparent inflation-reducing policy regimes. 
However, the answer is less straight-forward if we compare an inflation-targeting regime with an alternative monetary policy approach which puts greater emphasis on real economic outcomes. It is also important to recognize that inflation targeting regimes, in practice if not in theory, often include significant scope for discretionary responses, including monetary policies to address potential problems with real economic performance. In some respects, we are faced with a continuum. On one extreme, in a strict rules-based inflation targeting framework, all weight would be placed on reaching the desired inflation target. As we move away from this position, more weight is placed on real economic variables. Inflation targeting as a framework of 'constrained discretion' tends to consider real economic factors only in the context of short-run stabilization. We have argued in this paper that the conduct of monetary policy in the African context may also have important implications for long-run development. Can the inflation-targeting framework be extended to incorporate these considerations? Or does 'inflation targeting' lose its core objective if long-run development replaces long-run price stability as the central objective of central bank policy?

In some respects, this is a matter of semantics - a monetary policy that supports long-run development would also aim to control inflationary pressures and, in this respect, would need to manage inflation through transparent and accountable central banks. One concern is that the inflation targeting framework - even with substantial discretionary scope - precludes these long-run considerations. If so, a stronger case can be made for a developmental monetary policy for sub-Saharan African countries, one that takes into account a number of short-run variables with the ultimate aim of fostering long-run growth and development. 
Debating the merits of alternative monetary policies should not become an excuse for moving forward on institutional reforms, particularly financial sector reforms, to improve the development role of central banks. As we have stressed, the effectiveness of monetary policy, particularly a monetary policy which aims to support long-run development, will be determined by the quality of the institutions through which such policies operate. Monetary policy must be formulated and, when necessary, adjusted taking into account these institutional and structural realities. In addition, institutional reform should be seen as a critical component of monetary policy itself. Without recognizing these interconnections, central banks in Africa will be denied the possibility of playing a pivotal role in supporting economic development and poverty reduction. 


\section{References}

African Development Bank (AfDB), 2009a. "Africa and the Global Economic Crisis: Strategies for Preserving the Foundations of Long-term Growth." Working Paper 98 (July).

AfDB, 2009b. "Impact of the Crisis on African Economies - Sustaining growth and Poverty Reduction. African Perspectives and Recommendations to the G20." (March 21).

AfDB, 2009c. "Impact on the Global Financial and Economic Crisis on Africa." Working Paper 96 (March).

AfDB, UNECA, and OECD Development Center, 2009. African Economic Outlook 2008/09. Paris and Tunis: AfDB and OECD.

Aizenman, Joshua, Michael Hutchison, and Ilan Noy. 2008. "Inflation targeting and real exchange rates in emerging markets." NBER Working Paper 14561. National Bureau of Economic Research, Cambridge, MA.

Amoah, Benjamin and Zakari Mumuni. 2008. "Choice of monetary policy regime in Ghana," Working Paper, Bank of Ghana, Accra.

Arellano, M. and Stephen Bond. 1991. "Some tests of the specification for panel data: Monte Carol evidence and an application to employment equations." Review of Economic Studies 58: 277-97.

Aron, Janine and John Muelbauer. 2007. "Review of monetary policy in South Africa since 1994." Journal of African Economies 16(5): 705-44.

Aryeetey, Ernest and Jane Harrigan. 2000. "Macroeconomic and sectoral developments since 1970," in E. Aryeetey, J. Harrigan, and M. Nissanke, eds. Economic Reforms in Ghana: the Miracle and the Mirage, Trenton, NJ and Asmara, Eritrea: Africa World Press, pp. 5-31.

Ball, Laurence and Niamh Sheridan. 2005. "Does inflation targeting matter?" in B.S. Bernanke and M. Woodford, eds. The Inflation Targeting Debate. Chicago: University of Chicago Press, pp. 249-76.

Barbosa-Filho, Nelson H. 2008. "Inflation targeting in Brazil: 1999-2006." International Review of Applied Economics 22(2): 187-200.

Barnichon, Régis and Shanaka J. Peiris. 2008. "Sources of inflation in sub-Saharan Africa." Journal of African Economies 17(5): 729-46. 
Bernanke, Ben S., Thomas Lauback, Frederic S. Mishkin, and Adam S. Posen. 1999. Inflation Targeting: Lessons from the International Experience. Princeton, NJ: Priceton University Press.

Bernanke, Ben S. and Frederic S. Mishkin. 2007. "Inflation targeting: a new framework for monetary policy?" in F. Mishkin, ed. Monetary Policy Strategy, Cambridge, MA: MIT Press, pp. 207-26.

Bruno, Michael (1995) "Does inflation really lower growth?" Finance and Development, September: 35-38.

Bruno, Michael and Easterly, William. 1998. "Inflation crises and long-run growth." Journal of Monetary Economics 41: 3-26.

Burdekin, Richard C.K., Arthur T. Denzau, Manfred W. Keil, Thitithep Sitthiyot and Thomas D. Willett (2004). "When does inflation hurt economic growth? Different nonlinearities for different economies," Journal of Macroeconomics 3: 519-32.

Cardero, José Antonio. 2008. "Economic growth under alternative monetary regimes: inflation targeting vs. real exchange rate targeting." International Review of Applied Economics 22(2): 145-60.

Easterly, William 2002. "An identity crisis? Testing IMF financial programming". Center for Global Development. Working Paper No. 2. August.

Epstein, Gerald. 2008. "An employment targeting framework for central bank policy in South Africa." International Review of Applied Economics, 22(2): 243-58.

Epstein, Gerald. 2007. "Central banks as agents of employment creation," In J.A. Ocampo and Jomo K.S., eds. Towards Full and Decent Employment, London and New York: Zed Books.

Epstein, Gerald and Ervinç Yeldan. 2008. "Inflation targeting, employment creation, and economic development: assessing the impacts and policy alternatives." International Review of Applied Economics 22(2): 131-44.

Frenkel, Roberto and Lance Taylor. 2006. "Real exchange rate, monetary policy, and employment: development in a garden of forking paths" Working Paper. 19, UNDESA, United Nations, New York.

Friedman, Benjamin and Kenneth Kuttner. 1996. "A price target for U.S. monetary policy? Lessons from experiences with money growth targets." Brookings Papers on Economic Activity 1: 77-125.

Galindo, Luis Miguel and Ros, Jaime. 2008. "Alternatives to inflation targeting in Mexico." International Review of Applied Economics 22(2): 201-14. 
Ghosh, Atish and Steven Phillips. 1998. "Warning: inflation may be harmful to your growth.” International Monetary Fund Staff Papers 4: 672-86.

Gonçalves, Carlos E.S. and João M. Salles 2008. "Inflation targeting in emerging economies: what do the data say?" Journal of Development Economics 85: 31218.

Hadjimichael, Michael T., Dhaneshwar Ghura, Martin Mühleisen, Roger Nord, and E. Murat Uçer. 1995. Sub-Saharan Africa: Growth, Savings, and Investment, 198693. Washington, DC: International Monetary Fund.

Hodge, D. 2006. "Inflation and growth in South Africa." Cambridge Journal of Economics 30: 163-80.

IMF. 2005. World Economic Outlook. Washington, DC: International Monetary Fund.

Kasekende, L., Z. Brixiova, and L. Ndikumana, 2010. “Africa's counter-cyclical policy responses to the crisis." Journal of Globalization and Development (Symposium Edition), Vol. 1(1), article 16, January 2010.

Khan, Mohsin S. and Abdelhak S. Senhadji 2001. "Threshold effects in the relationship between inflation and growth." International Monetary Fund Staff Papers 1: 1-21.

King, Mervyn. 2005. "What has inflation targeting achieved?" In B.S. Bernanke and M. Woodford, eds. The Inflation Targeting Debate. Chicago: University of Chicago Press, pp. 11-16.

Kydland, Finn and Edward Prescott. 1977. "Rules rather than discretion: the inconsistency of optimal plans.” Journal of Political Economy, 85(June): 473-92.

Loening, Josef L., Dick Durevall, and Yohannes A. Birru. 2009. "Inflation dynamics and food prices in an agricultural economy: the case of Ethiopia," Policy Research Working Paper 4969, The World Bank, Africa Region.

Mankiw, Gregory N. 1985. "Small menu costs and large business cycles: a macroeconomic model of monopoly" Quarterly Journal of Economics 100(May): 529-39.

Mishkin, Frederic S. and Klaus Schmidt-Hebbel. 2007. "Does inflation targeting make a difference?" NBER Working Paper 12876, National Bureau of Economic Research, Cambridge, MA.

Mkandawire, Thandika (1999). "The political economy of financial reform in Africa." Journal of International Development 11:321-42. 
Nell, Kevin S. 2004. "The structuralist theory of imported inflation: an application to South Africa." Applied Economics, 36: 1431-44.

Oladipo, Olajide 2007. "Exchange rate pass through: a case study of a small open economy." Global Economy Journal 7(3): Article 4 (1-24).

Pollin, Robert and Andong Zhu. 2006. "Inflation and Economic Growth: A CrossCountry Non-linear Analysis." Journal of Post Keynesian Economics 4: 593-614.

Pollin, Robert, Mwangi Githinji, and James Heintz. 2008. An Employment-Targeted Economic Program for Kenya. Cheltenham, UK: Edward Elgar.

Rossouw, Jannie and Vishnu Padayachee. 2009. "Measuring inflation credibility: results of a first representative South African sample." South African Journal of Economics 77(2): 314-31.

Sacerdoti, Emilio (2005) "Access to Bank Credit in Sub-Saharan Africa: Key Issues and Reform Strategies.” IMF Working Paper 166, New York: International Monetary Fund.

Steele, William, Ernest Aryeetey, Hemamala Hettige, Machiko Nissanke (1997). "Informal financial markets under liberalization in four African countries." World Development 25(5): 817-30.

Thornton, John. 2008. "Money, output, and inflation in African economies." South African Journal of Economics 76(3): 356-66. 